\title{
INTERDEPENDENCE-BASED MODEL OF CONSISTENCY AMONG COMPETITION, COOPERATION AND COLLABORATION
}

\author{
Audrius Armas, Šarūnas Šniras \\ Lithuanian Sports University, Kaunas, Lithuania
}

\begin{abstract}
Research background and hypothesis. Social interdependence is evident in everyday human life situations; sports industry is based on it as well. Athletes often compete for higher achievements; however, a possibility for cooperation can be envisioned in competitions as well. The research problem is as follows: is it possible to harmonize social interrelations which manifest in competition, cooperation and collaboration at the same time, and how this consistency can be achieved.

The research aim was to elaborate the conceptual model of consistency among competition, cooperation and collaboration based on the premise of social interdependence.

Research methods were theoretical analysis and synthesis. The results of theoretical analysis were generalized and incorporated into the conceptual model.

Discussion and conclusions. Scientific literature suggested a few insights. First, social interaction may occur at two levels: intra-group (group level) and inter-group (community level). Second, the nature of social interdependence depends on the level of goals being achieved; three levels of goals can be distinguished: individual goals, group goals, and community goals. Third, based on the type of the interaction and the level of goals, individuals tend to engage into a particular form of interrelation: competition, cooperation, or collaboration; moreover, the form of interdependence is not restricted - a combination of a few (or even all) forms is possible. Based on scientific literature, an implication can be made that interrelation among competition, cooperation, or collaboration can result in coopetition as a higher form of interdependence.
\end{abstract}

Keywords: coopetition, social interaction, social interrelations.

\section{INTRODUCTION}

$\mathrm{R}$ elevance of the problem. Traditionally human social relationships are based on interactions. M. Deutsch (1949) argues that human social interactions are based on their interdependence. Furthermore, the essence of interdependence can manifest in positive, as well as in negative form. While analysing the phenomenon of social interdependence, D. W. Johnson and R. T. Johnson (2009) highlight that its positive manifestation can be envisioned in cooperation, whereas negative - in competition among individuals.
Both forms of social interdependence are evident in everyday human life situations; moreover, people face it at home, workplace, studies, or entertainment. It can be stated that sports industry is based on social interdependence as every other environment of human social self-expression. Athletes often compete for higher achievements; however, a possibility for cooperation can be envisioned in competitions as well. Scientific literature (e. g. Johnson, R. T., Johnson, D. W., 1999) suggests that competitors achieve better results when they cooperate in competition-based 
environment, rather when they compete without collaborating.

The scientific problem solved in the article was as follows: Is it possible to harmonize social interrelations which manifest in competition, cooperation, and collaboration in sport at the same time, and how this consistency can be achieved?

Accordingly, the research aim was to elaborate the conceptual model of consistency among competition, cooperation and collaboration based on the premise of social interdependence.

\section{RESEARCH METHODS}

Aiming at achieving the aim of the article, theoretical analysis and synthesis were carried out: scientific insights into the theory of Social Interdependence were analysed, interrelation between cooperation and competition was revealed, and afterwards, the theoretical implications on competition, cooperation and collaboration were provided. Consequently, the obtained results of theoretical analysis were generalized and incorporated into the conceptual model.

Social interdependence theory. Interdependence theory (IT) expands the formula proposed by K. Lewin (1946) that behaviour is a function of the person and the environment. In the context of social relationship, the interaction (I) that occurs between persons $\mathrm{A}$ and $\mathrm{B}$ is a function of both persons' respective tendencies in relation to each other in the particular situation of interdependence (S) in which the interaction occurs (Holmes, 2002). According to N. Parolia et al. (2011), social interdependence theory provides a structure to examine whether collaborative efforts promote behaviours that result in higher levels of success.

While analysing intergroup conflicts in team games, G. Bornstein (2003) emphasizes that the tension between the collective interest of the group and the interests of its individual members is unavoidable. D. W. Johnson and R. T. Johnson (2009) argue that social interdependence exists, when the outcomes of individuals are affected by their own and others' actions. Social interdependence theory can be named as a classic research background for human collaborating interrelations. Accordingly, the main premise of the theory is that: (1) individuals' interactions are being determined by the way in which goals are structured; (2) desired outcomes are obtained on the basis of these interactions. According to J. G. Holmes (2002), the two components together can be thought of as comprising the social situation.

Moreover, the application of social interdependence theory to education has become one of the most successful and widespread applications of social and educational psychology to practice (Johnson, 2003). E. g. S. Jowett and J. Nezlek (2011) propose that coach-athlete relationships contain the elements of interdependence, and analyse it in a framework of social interrelation theory. M. Deutsch (1949) can be named as the founder and leading developer of the theory; who has made a huge contribution into the field. According to D. W. Johnson and R. T. Johnson (2005), the theory was widely applied in practice with imperative to education.

Analysing human interrelations, D. W. Johnson and R. T. Johnson $(2005,2009)$ state that there are four possible situations occurring based on the relation between individuals' goal achievement and related actions (see Figure 1).

The typology provided in Figure 1 shows that besides social interdependence the authors identify social dependence (when individual's goal achievement is being affected by other individual's actions, but the reverse is not true), independence (when individuals' goal achievements are unaffected by each other's actions), and helplessness (when individuals cannot influence their or other's goal achievement). According to J. G. Holmes (2002),
Figure 1. Interrelations among individuals (Johnson, D. W., Johnson, R. T., 2005)

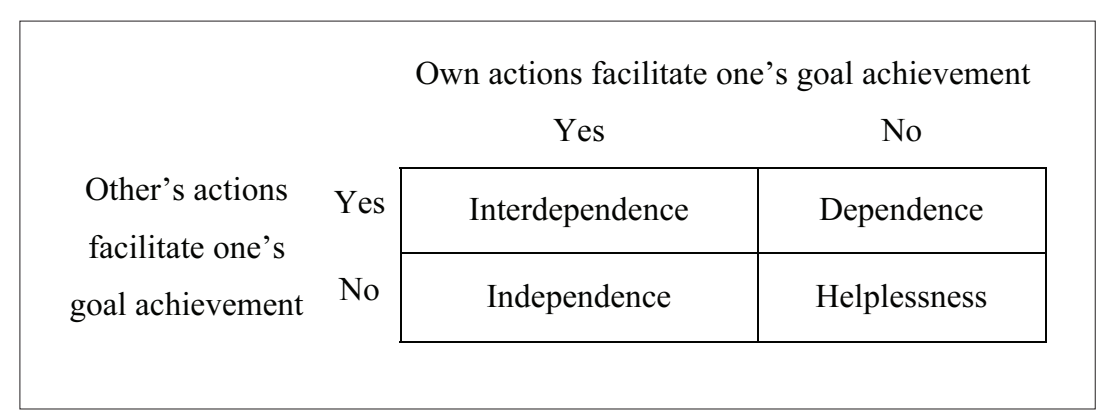


individual's own goals are consequent on social interaction.

Inhis initialtheory, its founder M. Deutsch(1949) identified two types of social interdependence: positive and negative. According to $\mathrm{D}$. W. Johnson and R. T. Johnson (2009), positive interdependence exists when there is a positive correlation among individuals' goal attainments; individuals perceive that they can attain their goals if and only if the other individuals with whom they are cooperatively linked attain their goals. Positive interdependence results in promotive interaction. J. Choi et al. (2011) state that positive interdependence can be seen in cooperation situations. Negative interdependence exists when there is a negative correlation among individuals' goal achievements; individuals perceive that they can obtain their goals if and only if the other individuals with whom they are competitively linked fail to obtain their goals (Johnson, D. W., Johnson, R. T., 2009). Negative interdependence results in oppositional or contrient interaction. J. Choi et al. (2011) propose that negative interdependence results in competition.

Furthermore, there is a possibility for a situation of no interdependence to occur (Johnson, Johnson, 2009). No interdependence exists when there is no correlation among individuals' goal achievements; individuals perceive that the achievement of their goals is unrelated to the goal achievement of others. According to J. Choi et al. (2011), no interdependence results in individualistic efforts.

Accordingly, the type of interdependence (i. e. positive or negative, or its absence) is determined by the structure of the goals of individuals in a particular situation; moreover, the outcomes of the situation are dependent on goal structure as well- because a goal is a desired future state of a situation. D. W. Johnson and R. T. Johnson (2005) propose that "a goal structure specifies the type of interdependence among individuals' goals. The type of interdependence determines how individuals must interact to achieve their goals." Therefore, an individual can influence and modify the concurrent situation by taking a particular course of actions: promote and facilitate the goal attainment of others (positive interdependence) or obstruct and block goal attainment of others (negative interdependence). D. W. Johnson et al. (2012) suggest that individual can ignore efforts of other people to achieve goals (no interdependence); such situation detaches a person from others, thereby creating non-substitutability, no inducibility or resistance, and cathexis only to one's own actions.

B. Enjolras and R. H. Waldahl (2007) propose that in sports, relationship exists when both sides of the relationship derive advantages from it. D. W. Johnson and R. T. Johnson (2005) argue that it is not enough to perceive positive or negative interdependence. People have to take actions to achieve a goal. As indicated before, latter actions result in cooperation (promotive actions) or competition (contrient actions). A situation resulting in taking individualistic efforts is also possible; however such situation is considered as being out of framework of current research because of its manifestation in the absence of interdependence.

Interrelation between cooperation and competition. The scientific analysis of social interdependence theory reveals cooperation and competition as two marginal opposite points of human interrelations. S. Attle and B. Baker (2007) highlight, that both competition and cooperation potentially impact student performance. Therefore, the insight can be made that consistency between two contraries may occur. T. Cerny and B. Mannova (2001) argue that the competition and cooperation among individuals will support the overall work; as the individual success benefits the whole team.

J. Decety et al. (2004) emphasize that cooperation and competition are two basic modes of social cognition that necessitate monitoring of both one's own and others' actions, as well as adopting a specific mental set. Analysing human evolution, the authors state that social cognition "arose out of a complex and dynamic interplay between two opposite factors: on the one hand, cooperation among individuals to form groups can provide enhanced security against predators, better mate choice, and more reliable food resources; on the other hand, competition between group members provides individuals with selective advantages in terms of mate selection and food procurement".

In a recent study on competitive and cooperative learning in senior secondary schools, E. B. Kolawole (2008) agrees with A. O. Akinbobola's (2006) findings that current educational system is based upon competition among students for grades, social recognition, scholarship and admission to top schools. The authors state that in our society and current educational framework, competition is valued over cooperation. However, when competition occurs 
between well-matched competitors, this is done in the absence of a norm-referenced grading system, and it is not used too frequently, it can be an effective way of motivating students to cooperate with each other (Cohen, 1994). K. Alexander and J. Luckman (2001), analysing the existing structures of Physical education programmes, propose combining the content (sport) and pedagogy (less teacher-directed; more student-managed) can emphasize collaboration and cooperation within a competitive structure. Taking the idea into consideration, S. Attle and B. Baker (2007) carried out research creating a team-like cooperation in a competitive business-like environment. By structuring learning activities the students are driven to cooperate in teams that compete against one another.

D. W. Johnson and R. T. Johnson (1994) describe three possibilities for student-to-student interaction: 1) a competition about who is the best; 2) an individual work where students do not need to pay attention at other students; 3) team cooperation where the students explore each other's contribution to the goal. T. Cerny and B. Mannova (2001) state that competition and cooperation among students will support the overall work, as the individual success benefits the whole team: the team cooperation encourages each other to do the assigned work, and learn to work together. After several analyses, D. W. Johnson and R. T. Johnson (1999) recognized the necessity to integrate cooperative learning and competitive individual learning. J. M. Tauer and J. M. Harackiewicz (2004) found that by combining cooperative group learning with inter-group competition intrinsic motivation of participants consistently improved. The findings suggest that a combination of cooperation and competition facilitates motivation, enjoyment, and performance of participants; students benefit from combining cooperative team learning strategies structured in an inter-group competition.

According to J. Decety et al. (2004), cooperation and competition involve executive functions and mentalizing abilities, both of which play a crucial role during social interactions. Executive functions encompass several aspects of generating flexible behaviour, including the ability to (a) choose a course of action in novel situations, (b) suppress a prepotent course of action that is no longer appropriate, and (c) monitor current ongoing action; mentalizing manifests in the ability to explain and predict the behaviour of the other by attributing independent mental states to them, such as thoughts, beliefs, desires, and intentions, which are different from our own. Acknowledging the touch-points of the two dimensions, E.A. Wynne (1995) proposed a synthesized cooperation-competition instructional strategy, where positive aspects of both cooperative learning and motivational competition using intergroup competition between collaborative teams were combined.

While analysing the consistency between cooperation and competition, K. G. Ricketts and J. A. Bruce (2009) use a term coopetition to maintain the idea of the interrelation existence. Accordingly, the term comes from the business and management field, and is used to describe: "a business situation in which independent parties co-operate with one another and co-ordinate their activities, thereby collaborating to achieve mutual goals, but at the same time compete with each other as well as with other firms" (Zineldin, 2004). Y. Luo (2004) has developed a conceptual and typological framework of coopetition in which cooperation and competition simultaneously coexist; the model was modified by B. Bigliardi et al. (2011) (see Figure 2).

Considering the possibility of the consistency between positive and negative interdependence and endeavouring to proof the possibility of coopetition, detailed analysis of cooperation and competition were provided.

Implications on cooperation. D. W. Johnson et al. (2012) suggest that positive interdependence is a result of cooperation. S. Attle and B. Baker (2007) define cooperation as "a social process through which performance is evaluated and rewarded in terms of the collective achievements of a group of people working together to reach a particular goal".

M. Deutsch (2000) proposes that cooperation induces and is induced by perceived similarity in beliefs and attitudes, readiness to be helpful, openness in communication, trusting and friendly attitudes, sensitivity to common interests and de-emphasis of opposed interests, orientation toward enhancing mutual power rather than power differences, and so on.

D. W. Johnson and R. T. Johnson (2009) propose five variables which mediate the effectiveness of cooperation: (1) positive interdependence (structured by outcome, means, and boundary), (2) individual accountability (i. e. the lack of individual accountability may reduce feelings of 


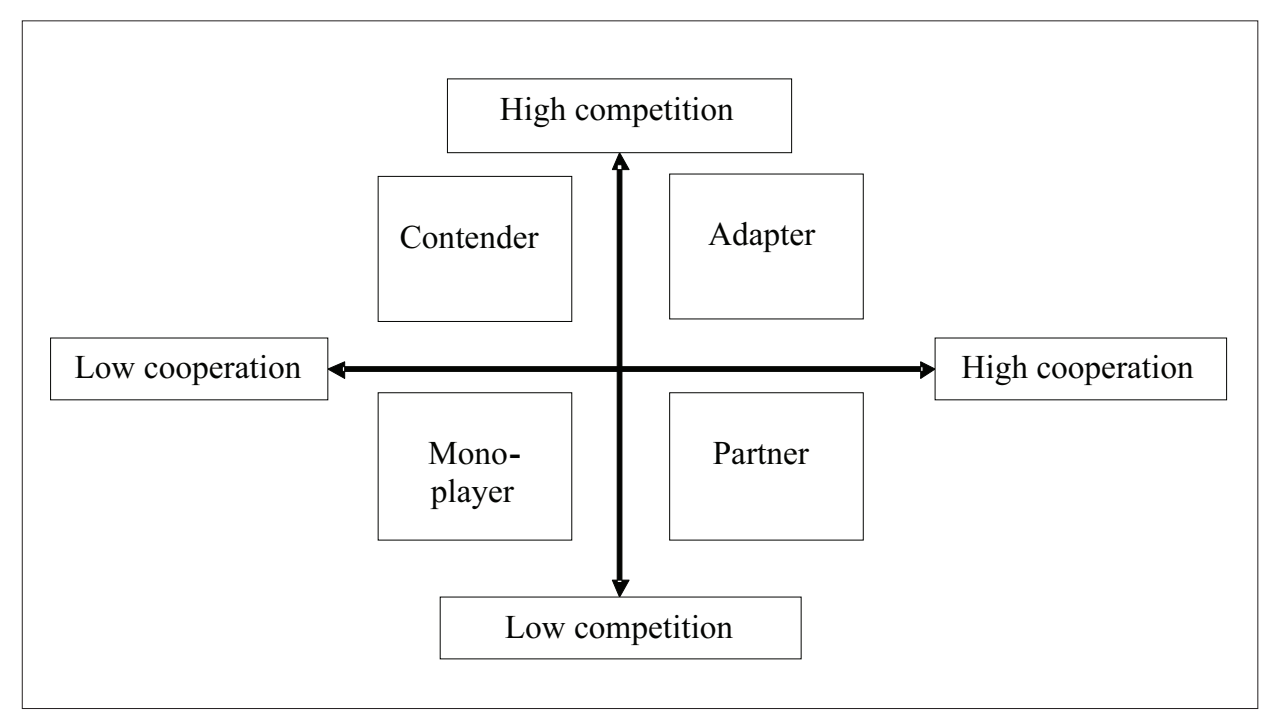

Figure 2. A typology of coopetition proposed by $Y$. Luo (Bigliardi et al., 2011)

personal responsibility), (3) promotive interaction (occurs as individuals encourage and facilitate each other's efforts to accomplish the group's goals), (4) the appropriate use of social skills (unskilled group members cannot cooperate effectively), and (5) group processing (clarifies and improves the effectiveness with which members carry out the processes necessary to achieve the group's goals). Successful cooperation is based on trust, commitment, and voluntary and mutual agreement that can be set out in a formal and documented contract or an informal contract aimed at achieving common goals (Osarenkhoe, 2010).

However, A. M. Thomson and J. L. Perry (2006) argue that cooperation for a mutual goal moves this to collaboration. Accordingly, collaboration is defined as a process in which autonomous actors interact through formal and informal negotiation, jointly creating rules and structures governing their relationships and ways to act or decide on the issues that brought them together; it is a process involving shared norms and mutually beneficial interactions. Moreover, collaboration was sometimes defined as needs of sharing, responsibility, getting more cooperation, constructing network and team working (Lucas, 1998).

As a group benefit, collaboration would create better teamwork as a result of mutual understanding through interpersonal interaction (Tschanen-Moran, 2001). Greater collaboration can foster greater trust as partners have experience with one another over time and have opportunities to witness benevolence, reliability, competence, honesty and openness of their partners.

Analysing differences between the two terms (often used as synonyms in scientific literature), O. Kozar (2010) indicates that cooperation can be achieved if all participants do their assigned tasks separately and bring their results to the table; collaboration, in contrast, implies direct interaction among individuals to produce a product and involves negotiations, discussions, and accommodating others' perspectives. Moreover, based on M. Zineldin's (2004) definition of coopetition, it can be envisioned that collaboration encompasses cooperation and coordination. Therefore, the major implication here is that cooperation is possible within a team, whereas collaboration occurs between two or more teams to reach their specific, as well as mutual goals.

Implications on competition. D. W. Johnson et al. (2012) suggest that negative interdependence results in oppositional or contrient interaction (such as obstruction of each other's goal achievement efforts, hiding resources and information from each other, acting in distrustful and distrusting ways); such negative interaction is called competition.

The definition of competition provided by J. J. Coakley (1997) is a social process that occurs when rewards are given to people on the basis of how their performances compare with the performances of others doing the same task or participating in the same event. The competition is evident throughout our society, our lives, and our recorded history. Of the three interaction patterns, competition is presently the most dominant. 
M. Deutsch (2000) suggests that competition can vary from destructive to constructive. In constructive competition, the losers as well as the winners gain. Therefore, competition induces and is induced by use of tactics of coercion, threat, or deception; attempts to enhance the power differences between oneself and the other; poor communication; minimization of the awareness of similarities in values and increased sensitivity to opposed interests; suspicious and hostile attitudes; the importance, rigidity, and size of issues in conflict; and so on.

D. W. Johnson and R. T. Johnson (2009) argue that competition tends to be more constructive when three conditions are met:

1. Winning is relatively unimportant;

2. All participants have a reasonable chance to win;

3. There are clear and specific rules, procedures, and criteria for winning.

Summarizing, it can be argued that constructive competition can be considered as a form of positive interrelation rather than negative.

Conceptualization of consistency between Cooperation, Collaboration and Competition. Scientific literature analysed, suggests a few insights into the field. First, social interaction may occur at two levels: intra-group (group level) and inter-group (community level). Second, the nature of social interdependence depends on the level of goals being achieved; three levels of goals can be distinguished: individual goals, group goals, and community (formation of few interrelated groups) goals. Third, based on the type of the interaction and the level of goals, individuals tend to engage into a particular form of interrelation: competition, cooperation, or collaboration; moreover, the form of interdependence is not restricted - a combination of a few (or even all) forms is possible. Moreover, based on scientific literature, an implication can be made that interrelation among competition, cooperation, or collaboration can result in coopetition as a higher form of interdependence.

Latter insights can be incorporated into an interdependence-based conceptual model of consistency among competition, cooperation and collaboration (see Figure 3). In a proposed model it can be seen that Individual (e. g. athlete) is a part of a Group (e. g. sports team), and the Community (e. g. two or more competing teams). Community encompasses Group as its component. Actions and interdependence of members within a particular
Figure 3. A model of consistency among competition, cooperation and collaboration

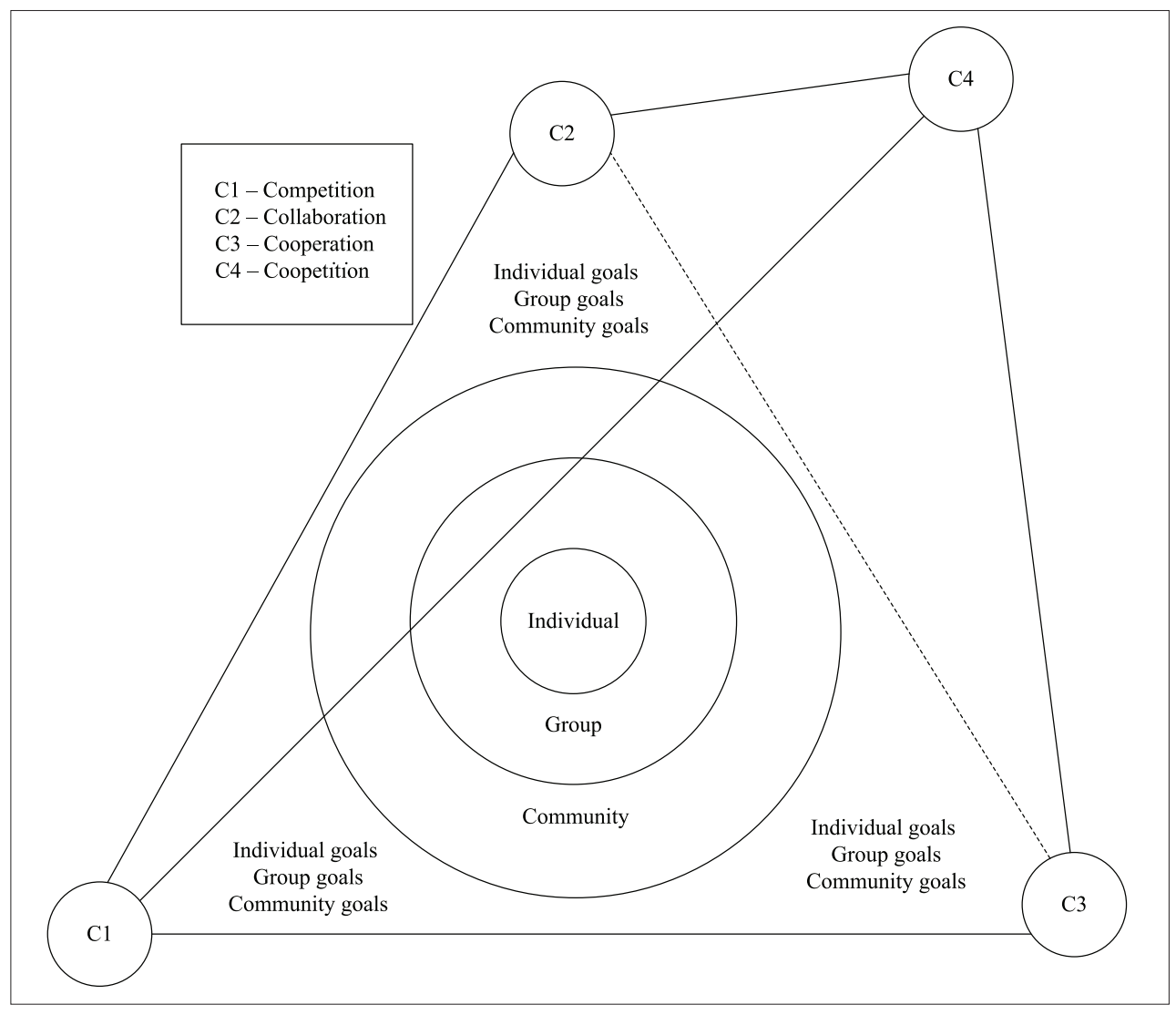


community (i.e. among individuals as group members; among groups as community members) are dependents on the goals. Moreover, depending on a level of a goal (individual, group, or community) a most appropriate form of interrelation is chosen: Competition, Cooperation, or Collaboration. Assuming an existence of multiple goals (e. g. an athlete may want (1) his team to win a competition, and (2) to be the best in his team at the same time), few forms of interdependence can occur at a time; their consistency results in coopetition.

The proposed model can be seen as conceptual; therefore, the level of consistency and its essential structural parts have to be revised depending on a particular situation of social interaction (e. g. model structure may differ in a team game and individual game situation). Moreover, structural components of competition, cooperation and collaboration have to be established and adjusted to the environmental conditions of the situation.

\section{CONCLUSION AND PERSPECTIVES}

Scientific analysis has revealed a high possibility of consistency among competition, cooperation and collaboration in social interrelations. Various discussions about an impact of the form of interdependence on goal achievement have been found. Moreover, a huge scientific substantiation for a synergy among the latter three forms of interrelations has been found in the fields of psychology, sociology, management and education. It can be stated that sport is being affected by all the above mentioned fields of science and their insights. Moreover, sport is often related to competition; however, team members are likely to cooperate inside the team.

A vast majority of researchers suggest that competition alone is not substantial for goal attainment. However, a constructive competition is often more productive in terms of achievements than destructive. Considering a constructiveness of competition, structural features of cooperation or collaboration can be envisioned. The constructiveness results in advising a competitor, or even helping to recognize former mistakes (e. g. made during the tennis match).
The analysis of goals of interaction has revealed an eventual goal typology. Depending on their subject and object, goals can be classified into individual level (athlete's goals), intra-group level (team goals), and inter-group level (game goals) goals. Individual goals are being achieved by a person acting alone or within a group, streaming to fulfil personal expectations (most often to excel over others); intra-group (group) level goals are those of group members working together (to attain a common group excellence in some specific field or in comparison to other groups); inter-group (community) level goals are those being achieved by several groups working together (either for better results in the field or for group's excellence in a context of other groups). Considering the essence of the goals being attained, the level of consistency and its structural parts can be modified. Various researchers suggest a term "coopetition", which reflects a possibility and even advantage of harmonization of competition, cooperation, and collaboration.

However, despite numerous research and substantial theoretical and practical insights, many obscurities and ambiguities in scientific literature concerning social interdependence in forms of cooperation and collaboration have been detected, as well. Terms of cooperation and collaboration are often used as synonyms, without paying attention to their conceptual difference. Therefore, other researchers emphasize the existence of such difference. Scientific analysis enabled to distinguish the following forms of interdependence; accordingly, cooperation was considered as a form of positive interrelation within a group (intra-group level), whereas collaboration - as a form of positive interrelation among two or more groups (intergroup level).

Considering the implications for further research, few imperatives can be suggested. Aiming at harmonizing competition, cooperation and collaboration, it is necessary to determine essential human skills and abilities for every category; their main touch-points have to be established. Moreover, prerequisite and optional environmental conditions have to be defined. In a framework of sport, empiric research is to be made in different kinds of sport: individual, pair or team-based. 


\section{REFERENCES}

Akinbobola, A. O. (2006). Effects of cooperative and competitive learning strategies on academic performance of students in Physics. Journal of Research in Education, 3 (1), 1-5.

Alexander, K., Luckman, J. (2001). Australian teachers' perceptions and uses of the Sport Education Curriculum Model. European Physical Education Review, 7 (3), 243-267.

Attle, S., Baker, B. (2007). Cooperative learning in a competitive environment: Classroom international. Journal of Teaching and Learning in Higher Education Applications, 19 (1), 77-83.

Bigliardi, B., Dormio, A. I., Galati, F. (2011). Successful co-opetition strategy: Evidence from an Italian consortium. International Journal of Business, Management and Social Sciences, 2 (4), 1-8.

Bornstein, G. (2003). Intergroup conflict: Individual, group, and collective interests. Personality and Social Psychology Review, 7 (2), 129-145.

Cerny, T., Mannova, B. (2011). Competitive and collaborative approach towards a more effective education in computer science. Contemporary Educational Technology, 2 (2), 163-173.

Choi, J., Johnson, D. W., Johnson, R. (2011). Relationships among cooperative learning experiences, social interdependence, children's aggression, victimization, and prosocial behaviours. Journal of Applied Social Psychology, 41 (4), 976-1003.

Coakley, J. J. (1997). Sport in Society: Issues and Controversies (6th ed.). Irwin, CA: McGraw-Hill.

Cohen, E. G. (1994). Restructuring the classroom: Condition for productive small groups. Review of Educational Research, 64 (1), 1-35.

Decety, J., Jackson, P. L., Sommerville, J. A., Chaminade, T., Meltzoff, A. N. (2004). The neural bases of cooperation and competition: An fMRI investigation. NeuroImage, 23, 744-751.

Deutsch, M. (1949). A theory of cooperation and competition. Human Relations, 2, 129-152.

Deutsch, M. (2000). Cooperation and competition. In M. Deutsch, P. T. Coleman, The Handbook of Conflict Resolution: Theory and Practice (pp. 21-40). San Francisco: Jossey-Bas Publishers.

Enjolras, B., Waldahl, R. H. (2007). Policy-making in sport: The Norwegian case. International Review for the Sociology of Sport, 42 (2), 201-216.

Holmes, J. G. (2002). Interpersonal expectations as the building blocks of social cognition: An interdependence theory perspective. Personal Relationships, 9 (1), 1-26. Johnson, D. W., Johnson, R. T. (2009). An educational psychology success story: Social interdependence theory and cooperative learning. Educational Researcher, 38, 365-379.
Johnson, D. W., Johnson, R. T. (1994). An overview of cooperative learning. In J. Thousand, A. Villa, A. Nevin, Creativity and Collaborative Learning: A Practical Guide to Empowering Students and Teachers (pp. 3143). Baltimore, MD: Paul H. Brookes.

Johnson, D. W., Johnson, R. T. (2005). New developments in social interdependence theory. Genetic, Social \& General Psychology Monographs, 131 (4), 285-358.

Johnson, D. W. (2003). Social interdependence: The interrelationships among theory, research, and practice. American Psychologist, 58 (11), 931-945.

Johnson, D. W., Johnson, R. T., Tjosvold, D. (2012). Effective cooperation, the foundation of sustainable peace. In P. T. Coleman, M. Deutsch, Psychological Components of Sustainable Peace: An Introduction (pp. 21-40). New York: Springer Science+Business Media. Johnson, R. T., Johnson, D. W. (1999). Making cooperative learning work. Theory into Practice, 38 (2), 67-73.

Jowett, S., Nezlek, J. (2011). Relationship interdependence and satisfaction with important outcomes in coach-athlete dyads. Journal of Social and Personal Relationships, 29 (3), 287-301.

Kolawole, E. B. (2008). Effects of competitive and cooperative learning strategies on academic performance of Nigerian students in mathematics. Educational Research and Review, 3 (1), 33-37.

Kozar, O. (2010). Towards better group work: Seeing the difference between cooperation and collaboration. English Teaching Forum, 2, 16-23.

Lewin, K. (1946). Action research and minority problems. Journal of Social Issues, 2 (4), 34-46.

Lucas, J. R. (1998). Balance of Power. New York: AMACOM.

Luo, Y. (2004). A co-opetition perspective of MNChost government relations. Journal of International Management, 10, 431-445.

Parolia, N., Jiang, J. J., Klein, G., Sheu, T. S. (2011). The contribution of resource interdependence to IT program performance: A social interdependence perspective. International Journal of Project Management, 29 (3), 313-324.

Ricketts, K. G., Bruce, J. A. (2009). “Co-opetition?” Can it exist between extension and agricultural education? A study on interdisciplinary cooperation. Journal of Extension, 47 (5) [2012 10 27]. Internet link: http:// www.joe.org/joe/2009october/rb1.php; seen.

Osarenkhoe, A. (2010). A coopetition strategy - a study of inter-firm dynamics between competition and cooperation. Business Strategy Series, 11 (6), 343-362.

Tauer, J. M., Harackiewicz, J. M. (2004). The effects of cooperation and competition on intrinsic motivation and performance. Journal of Personality and Social Psychology, 86 (6), 849-861. 
Thomson, A. M., Perry, J. L. (2006). Collaboration processes: Inside the black box. Public Administration Review (Special Issue), 20-32.

Tschannen-Moran, M. (2001). Collaboration and the need for trust. Journal of Educational Administration, 39, 308-331.
Wynne, E. A. (1995). Cooperation-competition: An instructional strategy. Phi Delta Kappan Fastbacks, 387, $7-27$.

Zineldin, M. (2004). Co-opetition: The organisation of the future. Marketing Intelligence \& Planning, 22 (6/7), 780-789.

\title{
TARPUSAVIO PRIKLAUSOMYBE PAGRĮTAS KONKURAVIMO, KOOPERACIJOS IR BENDRADARBIAVIMO DERINIMO MODELIS
}

\author{
Audrius Armas, Šarūnas Šniras \\ Lietuvos sporto universitetas, Kaunas, Lietuva
}

\begin{abstract}
SANTRAUKA
Tyrimo pagrindimas ir hipotezė. Kasdienis žmonių gyvenimas yra neisivaizduojamas be jų socialinės tarpusavio priklausomybės. Tai pažymètina ir apie sportinę veiklą. Sportininkai dažniausiai konkuruoja siekdami aukštesnių ir geresnių rezultatų, tačiau jų susivienijimas (kooperacija) taip pat gali reikštis ir konkuruojant. Mokslinè problema keliama klausimu, kaip galima suderinti socialinius tarpusavio santykius, kuriuos tuo pačiu metu lemia konkuravimas, kooperacija ir bendradarbiavimas, kaip šio suderinimo pasiekti.

Tikslas - sukurti konceptualų socialinės tarpusavio priklausomybès prielaidomis pagristą konkuravimo, kooperacijos ir bendradarbiavimo derinimo modeli.

Metodai: teorijos analizè ir sintezè. Teorinių tyrimų rezultatai yra apibendrinti ir susisteminti konceptualiu modeliu.

Aptarimas ir išvvados. Mokslinė literatūra pateikia keletą ižvalgų. Pirma, socialinė sąveika gali pasireikšti dviem lygiais: grupės viduje (grupinis lygis) ir tarp grupių (bendruomenès lygis). Antra, socialinės tarpusavio priklausomybès prigimtis priklauso nuo siekiamų tikslų lygio (galimi trys tikslų lygiai - tikslai gali būti individualūs, grupiniai ir bendruomeniniai). Trečia, priklausomai nuo socialinès sąveikos tipo ir tikslų lygio asmenys siekia konkrečiu tarpusavio ryšiu formu pasitelkdami konkuravimą, kooperaciją ir bendradarbiavimą. Be to, tokios sąveikos formu gali būti ịvairių - galimas kelių ar net visų formų derinys. Mokslinè literatūra teigia, kad derinant konkuravimą, kooperaciją ir bendradarbiavimą galima pasiekti koopeticijos, kaip aukštesnès sąveikos formos.
\end{abstract}

Raktažodžiai: koopeticija, socialinè sąveika, socialiniai savitarpio santykiai.

Gauta 2012 m. spalio 29 d.

Received on October 29, 2012

Priimta 2013 m. kovo $8 \mathrm{~d}$.

Corresponding author Audrius Armas

Accepted on March 8, 2013

Lithuanian Sports University

Sporto str. 6, LT-44221 Kaunas

Lithuania

Tel 37069946944

E-mail auarma@gmail.com 